\title{
The Legitimacy of Private Lawyers Representing States Before International Tribunals
}

\author{
ANDREAS R. ZIEGLER AND KABRE R. JONATHAN
}

\subsection{Introduction}

International adjudication, i.e. the use of international tribunals and arbitral bodies to decide international disputes, has experienced a rapid growth since World War II. While traditional arbitration may have experienced its heyday in the period between the Peace Conferences of 1899 and 1907, and thereafter until World War II, the number of international courts and tribunals has increased in the last 70 years and they are deciding more cases than ever before. This is particularly true in the area of international trade law, but to a lesser extent also in other fields such as border disputes and the law of the sea. ${ }^{1}$

This growth has been accompanied by a rise in challenges and difficulties for those courts and tribunals. One of these challenges is their legitimacy, ${ }^{2}$ which has been neglected for many years in the context of international law, for many reasons. ${ }^{3}$ We use a simple concept of legitimacy where the justification of the process and the acceptance of the actor are of primary importance, as discussed in more detail in Section 26.2. In recent years, however, the raison d'être of international adjudicative bodies

\footnotetext{
1 We have deliberately not included arbitral procedures in so-called Investor-State Dispute Settlement (ISDS) in this chapter. While this may be one of the most interesting areas of the use of private lawyers (and especially large international law firms) we have limited the scope of this contribution to procedures involving States only. Future work will certainly be undertaken to see to what extent the presence of non-State actors as parties to a dispute alters the finding of this contribution. The same is true for the dispute settlement system of the World Trade Organization (WTO), where many (developing) States are using highly specialized law firms. Where useful, specific references to this system have been included in this chapter without an in-depth analysis that would go beyond its scope.

${ }^{2}$ For a definition of how this term is used in this contribution see below Section 2.2.

3 See Christopher A. Thomas, 'The Uses and Abuses of Legitimacy in International Law' (2014) 24(4) The Oxford Journal of Legal Studies 730-732.
} 
and their (dis)advantages are increasingly debated. ${ }^{4}$ This debate affects the acceptance of international tribunals, ${ }^{5}$ their functioning, ${ }^{6}$ and the behaviour of some of their key actors. Among those actors, only the role of private counsel is the object of analysis in this contribution. Although these lawyers cannot be properly described as 'unseen actors' (because they are 'seen' performing some roles for litigant parties and their function of assistance to litigant parties is expressly enshrined in international texts), the legitimacy of assigning them certain 'unseen' roles merits discussion. ${ }^{7}$

As Jean-Pierre Cot (a Member of the International Tribunal of the Law of the Sea (ITLOS) since 2002) has stated, private counsel have always played an important role in international litigation.' ${ }^{8}$ Nonetheless, their role has been subject to many criticisms, ${ }^{9}$ the main one being their

4 An international adjudicative body can be defined as 'a dispute resolution mechanism that decides disputes between litigants, at least one of whom is a state'; see, for example, Nienke Grossman, 'Legitimacy and International Adjudicative Bodies' (2009) 41 The George Washington International Law Review 107, 111.

5 This is particularly true for more complex international tribunals that go beyond Stateto-State dispute settlement. For instance, Bolivia, Ecuador, and Venezuela denounced the Convention on the Settlement of Investment Disputes between States and Nationals of Other States (ICSID Convention), 18 March 1965, into force 14 October 1966 (1967), See Grossman, 'Legitimacy and International Adjudicative Bodies', 107-108. In addition, the Republic of Burundi and the Republic of the Philippines withdrew their membership from the Rome Statute of the International Criminal Court, 17 July 1998, into force 1 July 2002 (37 ILM (1998) 999; UN doc. A/CONF.183/9 of 17 July 1998), which is the founding treaty of the International Criminal Court, see www.icc-cpi.int/Pages/item.aspx?name=pr1371 (27 July 2018). The WTO Appellate body is also facing a crisis as the USA is blocking the appointment and reappointment of this body's members. Consequently, the Appellate Body is currently composed of only four members instead of seven and, if nothing is done, this Body will be unable to operate by 10 December 2019, see www.wto.org/english/tratop_ e/dispu_e/ab_members_descrp_e.htm (27 July 2018).

6 This issue has already been addressed, in a more general way, by various scholars, notably Grossman, 'Legitimacy and International Adjudicative Bodies'; Susan D. Franck, 'The Legitimacy Crisis in Investment Treaty Arbitration: Privatizing Public International Law Through Inconsistent Decisions' (2005) 73 Fordham Law Review 1521; Nienke Grossman, 'The Normative Legitimacy of International Courts' (2013) 86 Temple Law Review 61; Tullio Treves, 'Aspects of legitimacy of International Courts and Tribunals' in Rüdiger Wolfrum and Volker Röben (eds.), Legitimacy in international Law (Springer, 2008), pp.169-188.

${ }^{7}$ In their unseen role, we are talking about the representation of a litigant State by a private lawyer. This role is not expressly enshrined in international texts, see below pp. 7-8.

8 Jean-Pierre Cot, 'Appearing "for" or "on Behalf of" a State: The Role of Private Counsel Before International Tribunals', in Nisuke Nando, Edward McWhinney, Rüdiger Wolfrum, and Betsy Baker Röben (eds.), Liber Amicorum Judge Shigeru Oda, vol. II, (Kluwer Law International, 2002), p. 835.

9 See WTO, Panel Report, European Communities - Regime for the Importation, Sale and Distribution of Bananas, adopted 22 May 1997, WT/DS27/R/GTM, p. 294, para. 7.12; see also criticisms examined in Section 3.1.1. 
legitimacy. The question is normally not whether those lawyers possess the necessary legitimacy to assume a specific role on behalf of a State but rather, what measures need to be undertaken to enhance their legitimacy. This chapter addresses this issue with particular attention to private counsel who act on behalf of developing countries, ${ }^{10}$ who use private lawyers more frequently than developed ones. Developing countries also regularly entrust private lawyers with more extensive tasks than developed States do, as the latter have large groups of specialized lawyers within their own administrations. ${ }^{11}$

Among international adjudicative bodies, this chapter surveys only tribunals adjudicating disputes between States and, more specifically, the International Court of Justice (ICJ) and ITLOS. This choice may be explained by the following methodological reasons. Firstly, the ICJ has a specific place in international adjudication given its position as an organ of the United Nations and as the only permanent court whose jurisdiction is not limited to a specific area of international law or specific region of the world and given its influence on the development of international law. As this inquiry may involve public international law interests, it would seem inconceivable to not include the most important public international court, also referred to as the World Court. Secondly, the ICJ and ITLOS clearly distinguish between the function of judges and the function of litigants' representatives. ${ }^{12}$ As this chapter investigates how international tribunals perceive the legitimacy of private lawyers representing States, this distinction may be very important. Thirdly, the transparency of tribunals' proceedings was a selection criterion. Before some tribunals, such as the WTO Dispute Settlement Body (DSB), proceedings are confidential. ${ }^{13}$

10 This expression has not received an official definition. For this study, developing countries are considered to be those that have become members of the Advisory Centre on WTO Law (ACWL) and Least Developed Countries (LDCs) that are entitled to the services of ACWL, making a total of 79 countries; see www.acwl.ch/download/ql/Services_of_the_ ACWL.pdf (03 July 2017).

11 See below

12 See Statute of the International Court of Justice, 26 June 1945, in force 24 October 1945, 3 Bevans 1179; 59 Stat 1031; TS 993; 39 AJIL Supp. 215, Article 17 (ICJ Statute); see also Statute of the International Tribunal for the Law of the Sea, United Nations Convention on the Law of the Sea, 10 December 1982, 1833 UNTS 396 X, Annex VI, Article 7(2) (ITLOS Statute). This is not the case in ICSID arbitration, for example, where States' representatives may act also as arbitrators.

${ }^{13}$ See, however, the interesting contribution by Jessica C. Pearlman, 'Participation by Private Counsel in World Trade Organization Dispute Settlement Proceedings' (1999) 30(2) Law and Policy in International Business 399-416. 
The same is traditionally true for arbitral proceedings. In contrast, the ICJ and ITLOS are characterized by the transparency of their proceedings as well as the availability of their reasoned decisions. References to other tribunals are included where relevant.

In their judgments, international courts and tribunals do not tend to refer to any discussions concerning the role of a private counsel representing a State, unless they perceive a specific problem. Whenever international adjudicative bodies do include such references, these form useful sources to identify the factors that influence the perception of whether the exercised authority of private counsel is legitimate. We suggest examining criticisms made by international adjudicative bodies, in their judgments, regarding private counsel's presence and participation in international dispute settlement proceedings (usually alongside official State representatives). Reviewing these criticisms serves to identify and discuss standards that could be used to enhance a private lawyer's legitimacy.

For methodological reasons, the present analysis first clarifies the framework of the study by defining the key terms at issue (Section 26.2) before looking at (Section 26.3) factors that may challenge or enhance private counsel's legitimacy (with a particular focus on how accountability can influence legitimacy and what needs to be done in order to clarify this liability and, consequently, enhance private lawyers' legitimacy). Section 26.4 summarizes the findings and suggests areas for further research.

\subsection{Terminology}

\subsubsection{Private Lawyers}

In this section, we define the term 'private lawyer', i.e. identify who appears as private counsel or agent in inter-State litigation, and explain why private lawyers are employed by developing States - sometimes even as agents and not simply as (additional) counsel. The term 'private counsel' is sometimes used in the literature as a synonym for 'private lawyer' (without clear differentiation as to the exact authority he or she has in specific proceedings). In this chapter, we clearly distinguish those situations where we think the exact powers make a difference, in particular, when it comes to the use of agents before certain international courts and tribunals.

The term 'counsel' has not been clearly defined in international texts, but is in practice often used as a synonym for 'advocate'. For example, 
according to Article 42(2) of the ICJ Statute, 'counsel or advocates before the Court' may assist the agents of States, whereby the use of the conjunction 'or' implies an equivalence between those two terms. ${ }^{14}$ The Study Group of the International Law Association (ILA) on the Practice and Procedure of International Courts and Tribunals proposed to consider as counsel,

any person discharging the functions of counsel by representing, appearing on behalf of, or providing legal advice to a party in proceedings before an international court or tribunal, however such person may be described, and whether or not the person has professional legal training or is admitted as a member of a bar association or other professional body ${ }^{15}$

According to this definition, the affiliation with a bar association or professional legal training is not a mandatory requirement. Rather, the focus lies on the functions performed: to be qualified as counsel, the person must represent, appear on behalf of, or provide legal advice to one of the parties to the dispute. This wide definition seems in the interest of State parties given the diversity of people who have appeared as counsel before internationals courts and tribunals, notably lawyers affiliated with a national bar, lawyers who are not affiliated with a national bar, ${ }^{16}$ and law professors. ${ }^{17}$ For the purpose of this chapter, only the case of private counsel (i.e. lawyers operating in private practice, to the exclusion of those working in the public administration) who are retained by foreign States other than their own governments is examined.

14 'The uniform current practice is to use the two terms interchangeably, or even conjointly. The distinction in kind is rather between "counsel and advocates", on the one hand, and "advisers" on the other', Sir Franklin Berman, 'Article 42' in: Andreas Zimmermann, Christian Tomuschat, Karin Oellers-Frahm, and Christian J. Tams (eds.), The Statute of the International Court of Justice, a Commentary, 2nd edn (Oxford University Press, 2012), pp. 1083-1084 (note 33).

15 Article 1 of The Hague Principles on Ethical Standards for Counsel Appearing before International Courts and Tribunals adopted 27 September 2010 (hereinafter The Hague Principles), available at www.ucl.ac.uk/laws/cict/docs/Hague_Sept2010.pdf (20 August 2017).

${ }^{16}$ For a definition of 'lawyer', see Arman Sarvarian, Professional Ethics at the International Bar (Oxford University Press, 2014), pp. 121-127.

17 According to Alain Pellet, the ICJ bar is composed 'almost exclusively of university professors', see Alain Pellet, 'The Role of the International Lawyer in International Litigation' in Chanaka Wickremasinghe (ed.), The International Lawyer as Practitioner, (British Institute of International and Comparative Law, 2000), p. 150. 
In inter-State adjudication, lawyers in private practice have expressly been charged to 'assist' litigant States and not to represent them. ${ }^{18}$ The main difference between 'assistance' and 'representation' lies in the binding powers of the State representative (also called agent): while the government needs to endorse the assistant's actions in order for the latter to be valid, the agent possesses the power to bind the represented State. ${ }^{19}$ It is the agent who receives communications on behalf of the litigant States, ${ }^{20}$ signs pleadings, ${ }^{21}$ and reads a party's final submissions. ${ }^{22}$ An agent may also appear as counsel and but not vice versa. ${ }^{23}$

Some international texts provide the counsel with a representative role but only for non-State actors (this contributes to the confusion that sometimes exists in the literature and statements made in public) ${ }^{24}$. Although private lawyers have not been expressly granted the role of State representative in legal documents, ${ }^{25}$ some (mainly developing) countries, based on the principle of free representation, have selected private lawyers instead of public servants or political figureheads as their representatives (agents). ${ }^{26}$ At the same time, the roles of the agent and counsel may

18 Article 42(2) ICJ Statute, Article 53 ITLOS Rules of the Tribunal (ITLOS/8) as adopted on 28 October 1997 and amended on 15 March 2001, 21 September 2001, and 17 March 2009, available at www.itlos.org/fileadmin/itlos/documents/basic_texts/Itlos_8_E_17_03_ 09.pdf (8 December 2017).

19 Sir Franklin Berman, 'Article 42', p. 1080 (note 10).

${ }^{20}$ Article 40(1), ICJ Rules.

${ }^{21}$ Article 52, ICJ Rules, Article 65, ITLOS Rules.

22 Article 60(2), ICJ Rules, Article 75(2), ITLOS Rules; see also Case concerning the Northern Cameroons (Cameroon v. United Kingdom), Oral arguments, ICJ Reports 1963, 15 (250).

${ }^{23}$ For an overview of the agent's role, see Michael J. Matheson, 'Practical Aspects of the Agent's Role in Cases Before the International Court' (2002) 1 Law and Practice of International Courts and Tribunals 467-479; see also Shabtai Rosenne, 'The Agent in Litigation in the International Court of Justice', in William Kaplan and Donald McRae (eds.), Law, Policy and International Justice: Essays in Honour of Maxwell Cohen (McGill-Queen's University Press, 1993), pp. 41-68.

24 Article 19 of the Statute of the Court of Justice of the European Union, Consolidated version of Protocol (No 3) on the Statute of the Court of Justice of the European Union, annexed to the Treaties, as amended by Regulation (EU, Euratom) No 741/2012 of the European Parliament and of the Council of 11 August 2012 (OJ L 228, 23.8.2012, p. 1).

25 This statement must be qualified if appearing 'on behalf of' a State (according to Article 292 of United Nations Convention on the Law of Sea, signed 10 December 1982, into force 16 November 1944, it is considered to be State representation. One author distinguishes between 'acting as a State representative' and 'acting on behalf of a State'; see Cot, 'Appearing "for" or "on behalf of" a State', pp. 835-848.

${ }^{26}$ Under international law, it is improper to consider as representation the fact that a State sends someone who will defend its interests before an international tribunal. The 
sometimes overlap in terms of their real influence on the dispute settlement proceedings and the representation of the States involved.

In contrast to developed countries, which usually possess sufficient legal capacity to take part in international proceedings in an effective manner, developing countries often lack the specific legal expertise necessary to successfully participate in those proceedings. ${ }^{27}$ Unfortunately, 'there is no systematic survey, both qualitative and quantitative, of the availability of international legal expertise in the foreign policy machinery of States in general, not to speak of developing countries. ${ }^{28}$ Nonetheless, it would seem that most developing States lack the required international legal expertise, ${ }^{29}$ so they need to call upon external resources to address this lack of human resources. Those external resources are usually found in private practice (international law firms) or among specialized academics offering their services; exceptionally an institutional mechanism may exist. For example, developing countries can have recourse to the legal aid services of a purposebuilt international organization, such as the WTO's Advisory Centre on WTO Law (ACWL). ${ }^{30}$ Otherwise, they must turn to international law firms.

Many governments have chosen this last option for counsel and sometimes even as agents. In proceedings before ITLOS, for instance, the majority of developing countries retain foreign lawyers also as agents. This has been the case of countries such as Saint Vincent and the Grenadines, ${ }^{31}$

proper representation in international law implies that the State's representative, the State represented and third persons are subjects of international law, see Angelo Piero Sereni, La représentation en droit international (Brill/Nijhoff, 1948), p. 80. However, many international texts use the word 'representation' to characterize the relationship between a country and its organ or employees who must defend its interests before international tribunals. Rosenne suggests using this expression in its 'accepted diplomatic sense', see Rosenne, 'The Agent in Litigation in the International Court of Justice', p. 61.

27 It seems that developed countries even tend to influence the awards of those adjudicative bodies, see Mark Daku and Krzysztof Pelc, 'Who Holds Influence over WTO Jurisprudence?' (2017) 20(2) Journal of International Economic Law 245-249.

${ }^{28}$ Cesare P.R. Romano, 'International Justice and Developing Countries (Continued): A Qualitative Analysis' (2002) 1(3) The Law and Practice of International Courts and Tribunals, 539-611, 557.

29 As noted in the preamble of the Agreement establishing the WTO ACWL. This remark, made in the context of the WTO DSB, may be extended to other international tribunals.

${ }^{30}$ Certain WTO members established the ACWL in order to 'provide developing countries and LDCs with the legal capacity necessary to enable them to take full advantage of the opportunities offered by the WTO', www.acwl.ch/acwl-mission/ (3 August 2017).

31 The $M / V$ 'SAIGA' Case (Saint Vincent and the Grenadines v. Guinea), Prompt Release, Judgment, ITLOS Report 1997, p. 16; The M/V 'SAIGA'(N²) Case (Saint Vincent and the Grenadines v. Guinea), Prompt Release, Judgment, ITLOS Report 1999, p. 10; 'Juno Trader' (Saint Vincent and the Grenadines v. Guinea-Bissau), Prompt Release, Judgment, ITLOS 
Guinea, ${ }^{32}$ Guinea-Bissau, ${ }^{33}$ Seychelles, ${ }^{34}$ Belize, ${ }^{35}$ and Panama. ${ }^{36}$ Before the ICJ, for example, Ethiopia, ${ }^{37}$ Liberia, ${ }^{38}$ Djibouti, ${ }^{39}$ and the Democratic Republic of Congo ${ }^{40}$ have been represented by private counsel.

Aside from the lack of legal capacity, the presence of private lawyers within governmental delegations is also due to the complexity of international courts' proceedings. To illustrate this complexity, 'WTO law consists of a complex web of over 20 agreements, which - together with the attached Member-specific schedules of concessions and commitments cover more than 20,000 pages' ${ }^{41}$ Procedural rules are often not sufficiently detailed to ensure that those who are not familiar with them can use those rules in an efficient way. This leads to the perception that opacity surrounds international proceedings.

In the case of international arbitration, for example, procedural rules can even be established on an ad hoc basis and officials of developing countries may often feel disoriented if they do not have prior experience in dealing with these kinds of issue. Against this background, private counsel who knows the 'rules of the game, the usual practice and even the layout' 42 of those courts and tribunals appears to have a comparative advantage over developing States' civil servants and other private practitioners.

Reports 2004, p. 17; M/V 'Louisa' (Saint Vincent and the Grenadines v. Kingdom of Spain), Judgment, ITLOS Reports 2013, p. 4.

32 The M/V 'SAIGA' Case (Saint Vincent and the Grenadines v. Guinea), Prompt Release, Judgment, ITLOS Report 1997, p. 16; The M/V 'SAIGA' $\left(N^{\circ} 2\right)$ Case (Saint Vincent and the Grenadines v. Guinea), Prompt Release, Judgment, ITLOS Report 1999, p. 10.

33 'Juno Trader' (Saint Vincent and the Grenadines v. Guinea-Bissau), Prompt Release, Judgment, ITLOS Reports 2004, p.17; M/V 'Virginia G' (Panama/Guinea-Bissau), Judgment, ITLOS Reports 2014, p. 4.

34 The 'Monte Confurco' Case (Seychelles v. France), Prompt Release, Judgment of 18 December 2000, p. 86.

35 The 'Grand Prince' Case (Belize v. France), Prompt Release, Judgment of 20 April 2001, p. 17.

36 The 'Camouco' Case (Panama v. France), Prompt Release, Judgment of 7 February 2000, p. 10; The 'Chaisiri Reefer 2' Case (Panama v. Yemen), Prompt Release, 13 July 2001, p. 82; M/V 'Virginia G' (Panama/Guinea-Bissau), Judgment, ITLOS Reports 2014, p. 4.

37 'South West Africa Cases (Ethiopia v. South Africa; Liberia v. South Africa), Preliminary Objections, Judgment of 21 December 1962: ICJ Report, 1962, p. 319.

38 Ibid.

39 Certain Questions of Mutual Assistance in Criminal Matters (Djibouti v. France), Judgment, I.C.J. Reports 2008, p. 177.

40 Armed Activities on the Territory of the Congo (Democratic Republic of the Congo v. Uganda), Judgment, ICJ Reports 2005, p. 168.

${ }^{41}$ See www.acwl.ch/acwl-mission/ (20 August 2017).

${ }^{42}$ Pellet, 'The Role of the International Lawyer in International Litigation', p. 149. 


\subsubsection{Legitimacy}

The concept of 'legitimacy' is not easy to define, ${ }^{43}$ even though many scholars have attempted over time to identify its constitutive elements. ${ }^{44}$ For the purpose of this chapter, legitimacy stands for the justification and the acceptance of a political authority. ${ }^{45}$ The private lawyer serving as counsel in international proceedings can be regarded as such a political authority because he or she plays an active role in inter-State proceedings. Through this assignment, the private lawyer is given a specific role in the representation of the State, including with regard to the outcome that will affect the State as such.

This authority may be legitimized by its source, its procedure, the outcomes it has produced, or a combination of these elements. ${ }^{46}$ In the case of counsel acting on behalf of a State, the question of legitimacy arises, in particular, in the case of private lawyers acting as agents, rather than as State counsel. In fact, the agent benefits from an important delegation of authority and can bind the represented country with his or her actions. ${ }^{47}$ Is the authority of the agent-lawyer perceived as legitimate? But even a simple counsel may play a very active role and a significant part in specific proceedings that justify the questions of his or her legitimacy.

43 Legitimacy may be described as a 'nebulous concept', see Yuval Shany, Assessing the Effectiveness of International Courts (Oxford University Press, 2014), p. 138; see also Thomas, 'The Uses and Abuses of Legitimacy in International Law', 733; Alain Pellet, 'Legitimacy of Legislative and Executive Actions of International Institutions' in R. Wolfrum and V. Röben (eds.), Legitimacy in International Law, p. 63.

44 Grossman, 'Legitimacy and International Adjudicative Bodies', 115-122; Thomas, 'The Uses and Abuses of Legitimacy in International Law', 734-742; Mattias Kumm, 'The Legitimacy of International Law: A Constitutionalist Framework of Analysis' (2004) 15 EJIL 907, 917.

45 Many scholars use this term in that way, see Grossman, 'Legitimacy and International Adjudicative Bodies', 115; see also various contributors in Wolfrum and Röben, Legitimacy in International Law, pp. 1-24, 25-62, 309-317; Nienke Grossman, Harlan Grant Cohen, Andreas Føllesdal, and Geir Ulfstein, 'Legitimacy and International Courts - A Framework' in Nienke Grossman, Harlan Grant Cohen, Andreas Føllesdal, and Geir Ulfstein (eds.), Legitimacy and International Courts, (Cambridge University Press, 2018), p. 3.

46 Rüdiger Wolfrum, 'Legitimacy in International Law from a Legal Perspective: Some Introductory Considerations' in Wolfrum and Röben (eds.), Legitimacy in International Law, p. 6.

47 See Berman, 'Article 42', pp. 1080-1083; see also Matheson, 'Practical Aspects of the Agent's Role in Cases before the International Court', 467-479; Rosenne, 'The Agent in Litigation in the International Court of Justice', pp. 41-68. 
In the context of international law, there are some important arguments in favour of the legitimacy of private lawyers being used as counsel (or even agent). The first argument is the consent of the represented State. ${ }^{48}$ The moment a private person is assigned by the State to represent this State before an international adjudicative body, this lawyer is 'legitimized' to exercise this authority on behalf of that State. ${ }^{49}$ Assuming that this is the free will of the competent State organs, this decision benefits from the same legitimacy as the appointing authority has under domestic law.

In addition, the specific expertise of the appointed counsel provides a strong argument in favour of the legitimate authority of private council (outcome-based legitimacy). Only the appointment of (foreign) private persons (experts) can assure the correct representation of certain States and the defence of their best interests ${ }^{50}$.

However, the present discussion is not focused on the actual legitimacy of the counsel but rather on the perception of this legitimacy. Is the authority of the agent-lawyer perceived as legitimate? Who must perceive the agent-lawyer's authority as legitimate in the context of international adjudication? In the case of private counsel, the relevant constituencies are first and foremost States, but also international adjudicatory bodies, potential litigants, and even the population (citizens) of the State appointing such a counsel. ${ }^{51}$ This chapter focuses exclusively on how international courts and tribunals perceive the exercise of public authority by lawyers on behalf of States, though the wider question on the legitimacy as perceived by other actors definitely deserves attention in future research.

\subsection{Factors Influencing Legitimacy}

Several criticisms regarding private counsels' legitimacy acting on behalf of governments are based on their supposed lack of proximity to the

48 Rüdiger Wolfrum, 'Legitimacy in International Law from a Legal Perspective: Some Introductory Considerations', in Wolfrum and Röben (eds.), Legitimacy in International Law, pp. 6-10.

49 Ibid., pp. 10-24. This State consent tends to be insufficient as the base of the legitimacy in some aspects of international law and must be completed with other elements such as the test of democratic governance, for example; ibid., pp. 20-24.

50 WTO, Appellate Body Report, European Communities - Bananas, adopted 9 September 1997, WT/DS27/AB/R, p. 7, para. 12; Permanent Court of Arbitration (PCA) case No. AA 227, Yukos Universal Limited (Isle of Man) v. The Russian Federation, Final award, 18 July 2014, p. 577.

${ }^{51}$ Shany, Assessing the Effectiveness of International Courts, p. 139. 
represented State (Section 26.3.1) and the vagueness of rules regulating their accountability (Section 26.3.2).

\subsubsection{Proximity with the Represented State}

\subsubsection{Private Counsel's Proximity to the Represented State}

As an introduction to this factor, we would like to give two examples: in a dispute between Belize and France, one member of ITLOS noted 'an unusual feature':

The Agent appointed by Belize is not well placed, as a non-Belizean lawyer in private practice in Spain, to explain to the Tribunal the seeming inconsistencies in the statements of different government departments and agencies in Belize..$^{52}$

In another case, an ICJ judge, made the following statement:

Furthermore, in the present case, I note that a State appearing before the Court is not represented by a person holding high office in the Government acting as Agent, but by a private lawyer from another, highly developed, country. This has rarely been the case in the history of the Court and reinforces my feeling that a question arises as to whether the case is brought to the Court in the interest of the State involved or for some other reason..$^{53}$

In those two cases, lawyers were criticized for being of a nationality other than that of the country for which they were acting and for not holding highest office in the local government ${ }^{54}$. An aggravating factor seemed to be that they were not only acting as counsel but also as agent for the States concerned. A legitimacy-influencing factor may be derived from those reproaches: the proximity of a legal representative with the represented country. The underlying idea is that the more the counsel (or at least the agent) has a close relationship with the represented country, the stronger his or her legitimacy. This proximity can be assessed using criteria such

52 The 'Grand Prince' Case (Belize v. France), Prompt Release, Judgment, Separate Opinion of Judge Anderson, 20 April 2001.

53 Armed activities on the territory of the Congo (Democratic Republic of the Congo v. Uganda), Provisional Measures, Order of 1 July 2000, I.C.J. Reports 2000, Declaration of Judge Oda, at 132 .

${ }^{54}$ In a recent case, the representativeness of a private lawyer acting as the State's representative was also questioned, see $M / V$ 'Norstar' (Panama v. Italy), Preliminary Objections, Judgment, ITLOS Reports 2016, pp. 18-26; see also Declaration of Judge Cot, ITLOS Reports 2016, p. 2. 
as nationality or participation in the performance of a public interest mission or the exercise of highest office in the country.

This standard could, however, simply have been influenced by governments' past practice (i.e. tradition) in terms of representation. ${ }^{55} \mathrm{In}$ fact, in their relations with others States and international organizations, States used to send delegations that included a head of delegation, other delegates, diplomatic staff, and administrative, technical, and service staff. ${ }^{56}$ Ministers or other persons holding high office in the represented governments used to be part of such delegations. ${ }^{57}$ Even if a State has the sovereign right to do so, the appointment of persons who do not possess its nationality seems more the exception than the rule. ${ }^{58}$ This practice could simply have led to the belief that State representation should be assumed by (high) government officials whose mission is to work on a daily basis for the safeguarding of a government's public interests. In the United States, for example, there is a difference in the traditional understanding between the role of governmental entities' attorneys and private parties' attorneys. In this traditionally 'adversarial' system both functions are described as attorneys but characterized differently. The first serve the public interest while the second, primarily, defend individual selfinterests of their private clients. ${ }^{59}$

In support of this legitimacy factor, it has been suggested that the absence of proximity between the agent and its government could result in improper consequences for the conduct of the international proceedings. This may be less true for other legal systems (such as those on the European continent), where many legal systems attribute specific duties in the public interest to private lawyers when defending private parties against the State.

55 In the years of the General Agreement on Tariffs and Trade (GATT), for instance, only government lawyers or government trade experts were representing governments in dispute settlement proceedings, see WTO, Appellate Body Report, European Communities Bananas, adopted 9 September 1997, WT/DS27/AB/R, pp. 5-6, paras. 8-9.

56 Article 45 of the Vienna Convention on the Representation of States in their Relations with International Organizations of a Universal Character, 14 March 1975 (hereinafter 'Vienna Convention') (Un Doc. A/Conf. 67/16; 1975 Digest of US Practice in International Law 40). 'Although this Convention has not yet entered into force, its Part 111 (Delegations to Organs and to Conferences) particularly represents a reflection of customary international law in this area', see Rutsel Silvestre J. Martha, 'Representation of Parties in World Trade Disputes' (1997) 31(2) Journal of World Trade 86.

57 Article 50, Vienna Convention.

58 Article 73, Vienna Convention; see also Shabtai Rosenne, The Law and the Practice of the International Court 1920-2005 (Brill, 2006), pp. 1120-1121.

59 Steven K. Berenson, 'Public Lawyers, Private Values: Can, Should, and Will Government Lawyers Serve the Public Interest?' (2000) 41(4) Boston College Law Review 796 ff. 
26.3.1.2 Consequences of the Lack of Proximity Between the Represented Government and its Counsel/Agent

The problems arising from non-proximity between authorities of represented government and counsel or agent are numerous. Only two of them are to be analysed here. Firstly, the private counsel can provide the tribunal with inaccurate information. As representative, the agent (and to a lesser degree the counsel) is the link between the court and the litigant State. Given this position, the agent is expected to be highly reliable. ${ }^{60}$ This requires legal expertise but also a good knowledge of local realities. When the agent is not a national (or at least resident) of the represented country, he or she may give the international tribunal incorrect information or be unable to provide all the information requested, notably when this information relates to the government's domestic affairs. In the Grand Prince Case, the agent appointed by Belize provided incomplete and contradictory information concerning the registration of the vessel and the position of Belize as to the nationality of the Grand Prince. ${ }^{61}$ Additionally, Judge Anderson 'would have favoured asking for more information about the legal status of the Grand Prince at the material times. ${ }^{62}$ But given the fact that the agent was not familiar with local practices of different government departments and agencies in Belize, the Tribunal decided 'not to seek further information from the Applicant'. ${ }^{63}$ In the Juno Trader Case, it seems that there was a divergence between information provided by the agent and the view of the law as it emerges from the decision of the Regional Court of Bissau. ${ }^{64}$

Judge Cot summed up the situation (under the particular circumstances typical for the application for release of a vessel under Article 292 of the UN Convention on the Law of the Sea): 'The lawyer-agent is not necessarily in close contact with the authorities of the flag State. The credibility and reliability of the information he provides as to the legal position of the flag State may be questionable. ${ }^{65}$

60 See Cot, 'Appearing "for" or "on behalf of" a State', p. 842. Another author adds that the agent has to 'understand and faithfully reflect the national policy decisions of its government', see Matheson, 'Practical Aspects of the Agent's Role in Cases Before the International Court', 473.

61 'Grand Prince', Declaration of Judge ad hoc Cot, para. 14.

62 'Grand Prince', Separate Opinion of Judge Anderson.

${ }^{63}$ Ibid.

64 'Juno Trader', Joint Separate Opinion of Judges Mensah and Wolfrum, 59.

65 'Grand Prince', Declaration of Judge ad hoc Cot, para. 14. 
Nevertheless, the proximity with national authorities does not guarantee that the information provided is credible and reliable. Even civil servants have provided false information in some proceedings ${ }^{66}$ or were unable to adequately defend the interests of their State.$^{67}$ If the civil servant does not possess relevant experience in international litigation, his or her knowledge of local matters may be insufficient to properly defend the interest of the government. Adding civil servants to a State delegation who will provide the international lawyer (possibly leading the delegation) with correct factual information might form a workable compromise. This may avoid contradictions between the information provided to a court and the facts (as occurred in the 'Juno Trader' case). ${ }^{68}$

Secondly, the lack of permanent association between the agentlawyer and the State he or she is representing can lead to a conflict of interests. Judge Oda underlined the risk of conflict of interests in at least one situation. ${ }^{69}$ Judge Cot also expressed his concern of 'a proliferation of applications that are manifestly unfounded inspired by law firms for reasons having nothing to do with the interests of the Applicant State.. ${ }^{70}$

Those conflicts can derive from multiple sources. Only a limited number of them can be discussed here. Firstly, besides the recourse to the judicial mode, States may use other amicable modes of international dispute settlement with a view to finding a diplomatic solution to a dispute: this is the obligation to negotiate. ${ }^{71}$ They have various means to fulfil this obligation,

${ }^{66}$ In one case (Maritime Delimitation and Territorial Questions between Qatar and Bahrain (Qatar v. Bahrain), Merits, Judgment, ICJ Reports 2001, p. 40), Qatar's representatives produced 82 false documents during the written proceedings. However, those documents were withdrawn after an objection from Bahrain. In this affair, Qatar was represented by the Secretary-General of the Cabinet of the Government of the State of Qatar and it seems that the outside counsel, retained by Qatar, had not been aware of any fraud, see $M / V$ 'Louisa', Separate Opinion of Judge Cot, ITLOS Reports 2013, 114.

${ }^{67}$ In the CDC Group Case, the governmental agents of the Republic of Seychelles have demonstrated their incompetence to defend their State's interests, notably with countermemorial incorrectly drafted and poor management of witness, see CDC Group PLC v. Republic of Seychelles, ICSID Case N ARB/02/14, 17 December 2003, 8.

68 The 'Juno Trader', Joint Separate Opinion of Judges Mensah and Wolfrum, 59.

69 Armed Activities on the Territory of the Congo (Democratic Republic of the Congo v. Uganda), Provisional Measures, Order of the 1 July 2000, ICJ Reports 2000, Declaration of Judge Oda, 132

70 'Grand Prince', Declaration of Judge ad hoc Cot, para. 13.

71 '(a) the parties are under an obligation to enter into negotiations with a view to arriving at an agreement, and not merely to go through a formal process of negotiation as a sort of prior condition for the automatic application of a certain method of delimitation in the absence of agreement; they are under an obligation so to conduct themselves that the 
notably 'negotiation, enquiry, mediation, conciliation, arbitration, judicial settlement, resort to regional agencies or arrangements. ${ }^{72}$ Depending on the type of dispute, it may be helpful to make use of other means and not only (ab)use of judicial means because the judicial settlement of international disputes is simply an alternative to the direct and friendly settlement of such disputes between the parties. ${ }^{73}$ In this situation, the private lawyers assisting a State may be confronted with conflicting interests since their expertise is mainly sought in the context of the judicial resolution and not the diplomatic resolution of the dispute. The private counsel, thereupon, may be tempted by 'abuse of the right to institute proceedings before the Court' without 'first exhausting diplomatic channels. ${ }^{74}$

Secondly, in the case of ITLOS prompt release disputes (Article 292 of the UN Convention on the Law of the Sea), the agent-lawyer may be tempted to give priority to private interests (those of the shipowner) at the expense of the represented government's interests. This special procedure is a form of diplomatic protection that provides shipowners, via the flag State, a fast-track procedure and direct access to ITLOS. ${ }^{75}$ The dispute remains intergovernmental but the interests of the shipowner are also involved. It is not unusual that the agent appointed by the State, appears to be, in reality, the shipowner's counsel. ${ }^{76}$ In such a case, it is reasonable to assume that this agent-lawyer will prioritize the interests of the shipowner over those of the flag State should those two interests conflict.

Thirdly, counsel fees are another potential source for a conflict of interests. The underlying idea is that some agent-lawyers can seek to let the procedure drag on as long as possible in their own economic interest. The WTO Panel in the EC - Bananas case underlined the risk of high counsel fees. ${ }^{77}$ The

negotiations are meaningful', see North Sea Continental Shelf, (Federal Republic of Germany v. Denmark), Judgment, ICJ Reports 1969, 48.

72 Article 33 of United Nations Charter.

73 Free Zones of Upper Savoy and the District of Gex, Order of the 19 August 1929, PCIJ, Serie A, No. 22, p. 13.

${ }^{74}$ Shigeru Oda, 'The Compulsory Jurisdiction of the International Court of Justice: A Myth? - A Statistical Analysis of Contentious Cases' (2000) 49 The International and Comparative Law 265.

75 Tullio Treves, 'Article 292', in Alexander Proelss (ed.), United Nations Convention on the Law of the Sea, A Commentary (Beck/Hart/Nomos, 2017), p. 1882.

76 In the 'Louisa' case, the personal lawyer of the shipowner was solely in charge of SaintVincent and the Grenadines' representation, given the withdrawal of governmental employees, $M / V$ 'Louisa', Separate Opinion of Judge Cot, 117.

77 'There was a question in our minds whether the admission of private lawyers to Panel meetings, if it became a common practice, would be in the interest of smaller Members 
ACWL is trying to solve this problem by offering services similar to those of law firms at a relatively low cost. ${ }^{78}$ However, the WTO-ACWL example is hard to transpose to other international adjudicative bodies given the difference in prices that may exist between lawyers' fees for disputes before different international courts and tribunals. For the time being, the WTOACWL remains unique, despite suggestions to use similar mechanisms, for example, in ISDS. ${ }^{79}$ Philippe Sands (who is himself very actively assisting governments in international proceedings) gives an interesting example of:

a case in which the lawyer [is] acting as counsel for a State but where the legal fees are being paid by a private actor with an interest in the case. The interests of private actor and of State are different. The lawyer gets different instructions, one set of instructions from the person paying the legal fees, and another set of instructions from the State that appears as the party before the proceedings. What is counsel to do? 80

There is no clear answer from the outset. All those problems revive the debate on counsel regulation at the international level, which is the second legitimacy-influencing factor.

\subsubsection{Clarity of Accountability Rules}

Our purpose is to establish a link between legitimacy and accountability, and to enhance this legitimacy through accountability. To do so, we examine the influence of accountability on the perception of legitimacy and establish the current situation of counsel accountability both in term of binding rules and regulatory authorities. Then, we conclude the examination by suggesting some ways of enhancing counsel liability.

In the analysis of a private counsel's legitimacy, accountability tends to be a key element for it is assumed that a legitimate actor is necessarily an accountable actor. Many scholars have underlined the relationship

as it could entail disproportionately large financial burdens for them', see Panel Report, European Communities - Bananas, p. 294, para. 7.12.

78 For an overview of ACWL's charges, see ACWL's website, www.acwl.ch/download/basic documents/management_board_docs/ACWL-MB-D-2007-7.pdf (6 August 2017).

79 For example, 'Investment treaty cases are within a range of 5 to 10 times more expensive than trades disputes', see Anna Joubin-Bret, Establishing an International Advisory Centre on Investment Disputes? E15Initiative (International Centre for Trade and Sustainable Development (ICTSD) and World Economic Forum, 2015), p. 2.

${ }^{80}$ Philippe Sands, 'Interaction between Counsel and International Courts and Arbitral Tribunals: Ethical Standards for Counsel', in Rüdiger Wolfrum and Ina Gätzschmann (eds.), International Dispute Settlement: Room for Innovations? (Springer, 2012), p. 128. 
between accountability and legitimacy. The main argument is that the absence of clarity in accountability rules could result in a crisis of confidence that may reflect negatively on legitimacy. ${ }^{81}$

Furthermore - and from the point of view of democratic legitimacy national law seems to have more legitimacy than international law, given the presence of accountable institutions at national level. ${ }^{82}$ This clarity may materialize with accountability rules that offer predictability and help counsel, litigant States, and other actors involved in international adjudication to plan their conduct accordingly.

\subsubsection{The Lack of Transparency of Counsel Accountability Rules}

Unlike the situation at the national level, there is no International Bar. ${ }^{83}$ The principal consequence is the lack of a clear normative framework for the regulation of private lawyers' actions before international courts. ${ }^{84}$ Nonetheless, there are some principles related to counsel conduct before certain tribunals. ${ }^{85}$ Do those principles also apply to agent-lawyers given

81 This WTO Panel was criticizing the lack of 'disciplinary rules' private lawyers have to comply with, see Panel report, European Community - Bananas, p. 294, para. 7.12; see also Doak Bishop, 'Ethics in International Arbitration', in Albert Jan van den Berg (ed.), Arbitration Advocacy in Changing Times, International Council for Commercial Arbitration (ICCA) Congress Series No. 15 (Kluwer Law International, 2011), p. 383; Franck, 'The Legitimacy Crisis in Investment Treaty Arbitration', 1584; Grossman, 'Legitimacy and International Adjudicative Bodies', 153.

82 Kumm, 'The Legitimacy of International Law', 924.

83 Judge James Crawford distinguishes between the situation of international criminal tribunals with an emerging international criminal law bar, the situation of courts and tribunals hearing inter-State disputes where it seems to be an invisible bar, and the situation of international investment tribunals where there is need of an international investment law bar, see James Crawford, 'The International Law Bar, Essence before Existence?' (January 2014) The University of Cambridge Faculty of Law Research Paper No. 19/2014, pp. 343-354.

84 The International Criminal Court's Code of Professional Conduct for Counsel stands out as an exception (annexed to Resolution ICC-ASP/4/Res.1, and adopted at the third plenary meeting on 2 December 2005, by consensus, available at www.icc-cpi.int/resourcelibrary/Documents/COPCEng.pdf (10 August 2017). It has limited relevance for our study given the fact that States are not litigants before this court, but this Code can provide basic principles for international lawyers' accountability.

85 Those principles may be found in texts such as the Code of Conduct for European Lawyers and the Charter of Core Principles of the European Legal Profession, adopted by the Council of Bars and Law Societies of Europe (CCBE), The Hague Principles on Ethical Standards for Counsel Appearing before International Courts and Tribunals adopted by the International Law Association (ILA), and the International Bar Association's (IBA) Guidelines on Party Representation in International Arbitration. 
the specific nature of the agent's function? 'As the agent is the representative of a sovereign State, is it conceivable that he be subject to the authority of a court whose jurisdiction depends upon the consent of that State?'86 Agents are not, by definition, responsible under international law. They do not engage their personal responsibility for acts performed within the framework of their mandate of representation. The represented State is responsible for the actions of its agent. ${ }^{87}$ However, some authors take exception to this conclusion and claim that agent-lawyers should face individual liability for their conduct ${ }^{88}$. We are also of the opinion that individuals acting before international courts and tribunals should be subject to specific rules and that their violations should lead to specific sanctions.

Nevertheless, at least one question remains. Which institution should be in charge of regulating private lawyers' behaviour before an international adjudicative body? Is it the international tribunal before which the private lawyer appears? ${ }^{89}$ Are the lawyer's national disciplinary bodies (public prosecutor, local court, bar association, and the like) well positioned? ${ }^{90}$ Is it the represented State? ${ }^{91}$ Is it a system of self-regulation with

86 'Grand Prince' Case, Declaration of Judge ad hoc Cot, para. 48.

87 Riad Daoudi, Notion de représentation en droit international public (Librairie Générale de Droit et de Jurisprudence, Paris, 1980), pp. 65-66.

88 'Grand Prince' Case, Declaration of Judge ad hoc Cot, para. 49; see also Stephan Wilske, 'Sanctions against Counsel in International Arbitration - Possible, Desirable or Conceptual Confusion?' (2015) 8(2) Contemporary Arabian Asian Journal 141, 164.

89 Those courts have no explicit powers to apply the basic principles identified above. Moreover, those tribunals are reluctant to use their inherent powers to challenge agentlawyers' accountability. It seems that such powers do not include the power to take disciplinary action against a lawyer, Fraport AG Frankfurt Airport Services Worldwide v. Philippines, ICSID Case No. ARB/03/ 25, Decision on Application for Disqualification of Counsel, 18 September 2008, para. 39. See also see Crawford, 'The International Law Bar, Essence before Existence?', p. 353.

90 Of course, they have a role to play in the regulation of counsel at international level. However, entrusting those bodies with the exclusive power to control lawyers appearing before international adjudicative bodies may give rise to confidentiality concerns, additional costs, interference with international process, etc., see Wilske, 'Sanctions against Counsel in International Arbitration', 149-153.

91 For international adjudicative bodies, it appears that agent-lawyers' accountability does fall under the authority of the represented government, see 'Grand Prince' Case, Declaration of Judge ad hoc Cot, para. 15. The represented State has some means to sanction counsel misconduct, notably by bringing that misconduct before its own domestic courts, but States rarely uses those means. But it is safe to assume that a government that relies on a private lawyer for the defence of its interests before an international court may not be able to properly regulate this counsel and sanction him/her in case of wrongdoing. 
advocates regulating themselves ${ }^{92}$ Another institution ${ }^{93}$ Usually, none of these has been provided expressly with the mission of regulating lawyers' actions at the international level.

The absence of any institution clearly in charge of regulating counsel behaviour, coupled with the lack of coordination between these different potential regulatory authorities, results in an 'ethical no man's land' in which counsel operate with total freedom. ${ }^{94}$

This all contributes to blurring counsel accountability and reinforces concerns regarding lawyers with almost unlimited powers that are not sufficiently counter-balanced and/or controlled. Personally, we are of the opinion that the existence of an 'International Bar' is not a necessary prerequisite for the regulation of counsel accountability. In fact, we would rather suggest that international adjudicative bodies' inherent powers are sufficient to deal with this issue. The appeal of entrusting international tribunals with the determination of the accountability of counsels or agents acting before them is twofold: to clarify their accountability and thereby enhance their legitimacy.

\subsubsection{Clear Accountability Rules for Enhanced Legitimacy?}

Legitimizing the public authority of international institutions, organs, and norms is one of the goals international courts are expected to attain (external legitimization). ${ }^{95}$ Their capacity to achieve this goal is directly linked to their own legitimacy in the eyes of their constituencies (internal legitimization). ${ }^{96}$ International lawyers may contribute to this internal legitimacy given their expertise (even more so due to the fact that they may subsequently be retained as judges especially in international arbitration) ${ }^{97}$

92 Before the ICJ, it appears that there is an acceptable system of self-regulation of the invisible bar, see Crawford, 'The International Bar, Essence before Existence?', pp. 349-350.

93 For example, the president of the Swiss Arbitration Association, Elliott Geisinger has called for the creation of a truly transnational body for the regulation of counsel appearing before international arbitral tribunals; see Elliott Geisinger, 'President's Message: Counsel Ethics in International Arbitration - Could One Take Things a Step Further?' (2013) 32(3) ASA BULL 2014455.

94 Catherine Rogers, 'Fit and Function in Legal Ethics: Developing a Code of Conduct for International Arbitration' (2002) 23(2) The Michigan Journal of International Law 341, 341-342.

95 Shany, 'Assessing the Effectiveness of International Courts', pp. 44-46.

96 Ibid., p. 137.

97 This appointment may enhance the image of international tribunals and their professionalism and provide additional justifications to support their authority, ibid., p. 147. 
This legitimacy-conferring capacity could be extended to counsel acting before international courts and tribunals because these lawyers form part of the regime to which international courts are meant to contribute ${ }^{98}$ and may be seen as having a contractual or quasi-contractual commitment visà-vis these courts. ${ }^{99}$

In addition, a detailed regulation, such as 'judicial formation governed by public international law', ${ }^{100}$ imposed by international public institutions may not be seen as favouring the private interests of law firms but rather the public interest of the international community in the administration of justice. ${ }^{101}$ This would also enhance the image of counsel appearing before these courts and provide additional justifications to support lawyers' authority as States' representatives.

Moreover, making international adjudicative bodies responsible for counsel's conduct at the international level may resolve many practical problems: it will resolve concerns about breaches of confidentiality, as well as restoring equal treatment among international lawyers since not all international lawyers are affiliated with national bars. Those who are affiliated with national bars may be subject to different rules of conduct given differences among legal traditions. International bodies will apply the same rules to all lawyers appearing before them. However, there is a risk of fragmentation of accountability rules because of the differences between international courts and tribunals but this could be minimized through a dialogue between these institutions.

Finally, international tribunals' inherent powers include not only the power to adopt rules of conduct for counsel (or agents if they are private

98 According to Principle (i) of 'The Charter of Core Principles of the European Legal Profession', adopted on 24 November 2006, the lawyer is an 'officer of the Court' or a 'minister of justice'.

99 Wilske, 'Sanctions against Counsel in International Arbitration', 163.

100 Hrvatska Elektroprivreda, d.d. v. Slovenia, ICSID Case No. ARB/05/24, Ruling regarding the participation of David Mildon QC in further stages of the proceedings, 6 May 2008, para. 33.

101 See also Stephan Schill, 'The Case for Public Regulation of Professional Ethics for Counsel in International Arbitration', Kluwer Arbitration Blog, 7 July 2017. International adjudicative bodies have a public function that goes beyond the private function to settle a dispute between litigant parties. In particular, those tribunals have to ensure the proper administration of international justice and to play a role in the clarification and the progressive development of international law, see Chester Brown, 'Inherent Powers in International Adjudication', in Cesare P.R. Romano, Karen J. Alter and Yuval Shany (eds.), The Oxford Handbook of International Adjudication (Oxford University Press, 2014), pp. 842-844. 
lawyers) $)^{102}$ but also the power to sanction. ${ }^{103}$ The latter is a more delicate matter, but it seems that international tribunals' reluctance to exercise this control is mainly due to political reasons. ${ }^{104}$ However, the public function of those tribunals means they need to take into consideration interests other than those of the parties to the dispute; an international case usually involves not only interests of the litigant States but also those of the international community in a whole. ${ }^{105}$

\subsection{Conclusions}

A private lawyer's legitimacy (especially when acting as an agent) is heavily dependent on his or her knowledge of the facts and the law as applicable to the State by which he or she was appointed. The lawyer must be competent to represent the State, which this chapter has defined in terms of 'proximity with the represented State'. In cases where this proximity does not exist, this may have a negative impact on the defence of the interests of the represented government. This finding seems not particularly surprising and is also known from domestic law (lawyer-client relationship) but problems in this respect have arisen in recent years before the international tribunals studied in this chapter.

Accountability is also important for the analysis of the legitimacy of the use of private lawyers before international courts given the fact that the more transparent the normative framework of counsel regulation is, the more these lawyers' legitimacy as State representatives will be enhanced. International tribunals can be entrusted with regulating counsel since, as international public actors, they possess the legitimacy and the inherent competence to do so. Some of them have already exercised control over

102 International Criminal Court paved the way with the adoption of a code for counsel. The ICJ took a step in that direction with the adoption of its Practice Direction that contains some rules for counsel's conduct.

103 International courts sanctioned counsel many times, see for example the Hrvatska Elektroprivreda, d.d. v. Slovenia case. The ICJ rebuked counsel in three cases, see Crawford, 'The International Bar, Essence before Existence?', pp. 349-350. In The Rompetrol Group N.V. v. Romania, ICSID Case No. ARB/06/3, Decision of the Tribunal on the Participation of a Counsel, 12 January 2010, para. 16, the Tribunal did not deny this power of control but rather restricted its scope.

104 See Fraport AG Frankfurt Airport Services Worldwide v. Philippines, para. 39; see also Cot, 'Appearing "for" or "on behalf of" a State', 847; Crawford, 'The International Bar, Essence before Existence?', p. 350.

105 Brown, 'Inherent Powers in International Adjudication', p. 844. 
counsel behaviour but a more widespread debate about the existing rules and necessary improvements would enhance the perception of private lawyers' legitimacy In turn, this could contribute to improving the legitimacy of international dispute settlement as a whole.

We agree with Judge Cot when he says ' $[t]$ hat these are difficult questions', continuing that '[i]t falls primarily to the States parties to a dispute to answer them. They, acting in sovereign fashion, organize their representation and the defence of their interests. They do so at their own risk. ${ }^{\prime 106}$ In sum, this chapter concludes that common international rules to safeguard the integrity and thereby the legitimacy of international dispute settlement are needed when it comes to the use of private lawyers as counsels and agents.

106 'Grand Prince', Declaration of Judge ad hoc Cot, para. 15. 